\title{
Urbanising the Rural
}

Local strategies for creating "new style" communities in China

\section{Lior Rosenberg}

\section{OpenEdition}

\section{Journals}

Electronic version

URL: http://journals.openedition.org/chinaperspectives/6279

DOI: 10.4000/chinaperspectives.6279

ISSN: 1996-4617

\section{Publisher}

Centre d'étude français sur la Chine contemporaine

\section{Printed version}

Date of publication: 1 September 2013

Number of pages: 63-71

ISSN: 2070-3449

\section{Electronic reference}

Lior Rosenberg, « Urbanising the Rural », China Perspectives [Online], 2013/3 | 2013, Online since 01 September 2016, connection on 28 October 2019. URL : http://journals.openedition.org/ chinaperspectives/6279; DOI : 10.4000/chinaperspectives.6279

(C) All rights reserved 


\title{
Urbanising the Rural
}

\author{
Local strategies for creating "new style" rural communities in China
}

\section{LIOR ROSENBERG}

\begin{abstract}
The transition from traditional rural residences to urban-like multi-storey buildings and from traditional villages to rural residential communities (shequ) is one of rural China's most profound developments of the early twenty-first century. Official discourse highlights the potential benefits for villagers, portraying the new residential communities as gateways to modernity and significant steps toward reducing inequality and disparity between the rural and the urban. Based on extensive research in two counties in Shandong and Anhui provinces, this article concludes that while imposing urban-like models of residence may coincide with prosperous communities' circumstances, it may easily become a statist venture of predation and a source of tension and rural discontent in less prosperous communities.
\end{abstract}

KEYWORDS: urbanisation, rural China, communities, inequality, state-society relations.

E arlier studies have made a distinction between two trajectories of urbanisation in China. The first path refers to state-planned development based on large-scale industries in China's large cities. The second refers to towns or small city-based urban developments that rely mainly on local initiatives and resources. (1) Laurence J.C. Ma and Ming Fan have entitled these "urbanisation from above" and "urbanisation from below." (2) At the heart of both trajectories of urbanisation, though, lies the same demographic phenomenon: migration of the farming populace away from rural areas into urban settlements in search of jobs and a better life.

In this article I focus on what may be perceived as a new stage of urbanisation in China. The innovativeness of China's new program lies in its scope, which transcends the normal scope of the urban (expanding cities/towns or expansion of successful villages into towns). Instead, it seeks to urbanise the rural by imposing urban-like models of residence on rural residents, many of whom are still farmers. As part of this, it is common that villages are merged with other villages, and villagers are moved into townhouses or multi-storey apartment buildings, creating a "new style" of rural residential communities (xinxing nongcun shequ 新型农村社区) with modern facilities and better services. Often local officials locate these new settlements adjacent to rural towns, serving as de facto suburbs and embodying new kinds of relations between rural and urban populaces by integrating both systems (services, labour markets, governing institutions, etc.). As David Bray demonstrates in his article in this journal issue, central and local state fiats and directives play a crucial role in determining the creation of these communities and their appearance. This policy is still in its experimentation stage and has mainly influenced the richer and more developed areas. Yet as this policy gains popularity within the Party and central government as a key factor to solving rural problems, it is not unrealistic to foresee that current experiments will be further expanded nationwide. As will be observed, while urban models of residence fit well with prosperous communities' circumstances, they do not match the local capabilities of less prosperous communities. Construction of residential communities requires significant financing, which local governments and villages may find hard to obtain. Moreover, urban-style residential compounds are not attuned to villagers' needs and traditions, a much more salient issue in agricultural communities than in industrialising ones.

\section{Methodology}

To investigate how the campaign of constructing rural communities was being implemented, I conducted extensive fieldwork over the period 20092011 in two counties - Chenggu County in Shandong Province and Beian County in Anhui Province. ${ }^{(3)}$ In total I studied six townships and some 20 villages in Chenggu and eight villages from six different townships in Beian. I conducted semi-structured interviews with officials from villages, townships, and the county level. In addition, I had numerous conversations, formal and informal, with village residents to learn about their perceptions and attitudes. These were mainly conducted in Chenggu, where I enjoyed better access to villages due to research permits and better transportation facilities.

Chenggu and Beian counties share several similarities. Both are located relatively close to provincial capitals (Jinan in Shandong and Hefei in Anhui); both are considered the most developed counties in their prefectures and one by no means considered poor; both are populated entirely by Han people; and both counties contain a population of about 700,000 people. Yet they differ significantly in terms of economic development. Chenggu is much more developed than Beian. Its total GDP is five times higher than Beian's, and the incomes of Chenggu's rural residents average 33\% higher. ${ }^{(4)}$ As an industrialised county, far more villages in Chenggu have substantial collective incomes (jiti shouru 集体收入) from land rentals and publiclyowned enterprises.

Research was done through the department of Political and Social Change, College of Asia and the Pacific, The Australian National University.

1. Huang Youqin, "Urban Development in Contemporary China," in Gregory Veeck et al. (eds.), China's Geography: Globalization and the Dynamics of Political, Economics and Social Change, Maryland, Rowman \& Littlefield Publishers, 2007, pp. 244-248.

2. Laurence J.C. Ma and Ming Fan, "Urbanization from Below: The Growth of Towns in Jiangsu, China," Urban Studies, Vol. 31, No. 10, 1994, pp. 1625-45.

3. To ensure anonymity, both counties' names have been changed.

4. Source: County Yearbooks, 2008. Available data refers to the year of 2007. 


\section{The "old" countryside - Impediments to modernity}

The emergence of a market economy in China starting in the 1980s was accompanied by an unfortunate expansion of economic and social disparity and inequality. The state has contributed significantly to this with its deliberate prioritisation of developing cities and the urban economy. Since the early 2000s, however, the Party has been pushing towards a redefinition of urban-rural relations. This was explicitly articulated in 2004, at the fourth plenum of the $16^{\text {th }}$ National Congress of the Communist Party (NCCPC), where Hu Jintao raised the thesis of the "two trends" (liang ge quxiang 两 个趋向). This locates the past and the future on a prolonged path of development, which allegedly coincides with "generalisable" trends of development. In this account, at initial stages of industrialisation there is a general trend for agriculture to support industries and villages to support cities. However, after a considerable level of industrialisation has been achieved, it is a trend to reverse these relations and push industries and cities to support rural communities. ${ }^{(5)}$ According to the Party, China was ready for a change of policy.

While the state has perceived its own role in the expansion of disparities as reversible, it has held as officially irreversible some of the most basic characteristics of rural life, which are deemed serious impediments to modernisation and China's prospects of establishing a developed national economy. Yang Shisong, a member of the leadership of a municipal Party School, points to five impediments. As this articulates official discourse, it is worthwhile recapping them one by one.

The first point refers to life inside villages, conceptualising the villages as "dirty (zang 脏), chaotic (luan 乱), and poor (cha 差)." Many surveys published inside the PRC have lamented rural areas' poor infrastructure and public amenities. A report published by the Academy of Social Sciences in 2005, for example, found that in the early 2000s, 300 million people in rural China still did not have permanent access to safe drinking water. ${ }^{(6)}$ About $50 \%$ of the villages did not have access to running water; 40,000 administrative villages were still inaccessible by public road; and roads to $70 \%$ of China's villages were not paved. In more than $50 \%$ of the villages people still used firewood and straw as sources of heating and cooking; 20 million people were still not connected to electricity; ${ }^{(7)} 7 \%$ of the villages did not have access to telephones, and 50 million villagers were not connected to TV or radio. ${ }^{(8)}$

Many villages in Beian and in the more developed county of Chenggu suffered unfortunate neglect. Most roads and alleys inside the villages were likely to be dirt, and villages became very muddy after rains. In Beian, arterial roads between villages were dirt as well, and transport was almost impossible after heavy rains or snow.

Most villages had poor hygienic environments. In many villages there was no separation between residences and livestock-raising areas, and in Beian the livestock wandered freely between houses in many of the villages. In most cases, villagers used soft coal for heating. There was no heating in many rural houses in Beian, and winter nights were very cold.Villagers used fire wood for cooking. Flush toilets were not common and people often disposed of the waste themselves.

When entering many of the villages in both counties, the first thing noticed was garbage thrown everywhere - on the main roads, in small alleys, drainage ditches, as well as in improvised dumps on the village outskirts. In many villages, arable land served as "empty-trash sites." Partly as result of

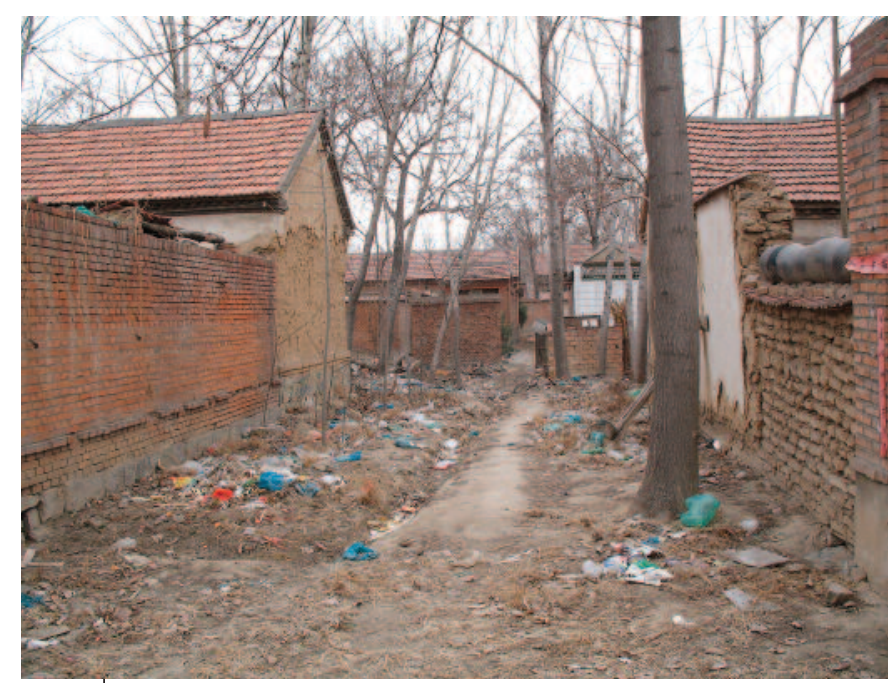

Photo 1 - A village in Chenggu County. @ Lior Rosenberg

villagers' lack of concern and cultural conventions, ${ }^{(9)}$ suitable means of disposing of garbage in the villages was lacking.

Villages also tended to lack cultural and leisure facilities. Public yards and sport facilities were very old and dilapidated, if they existed at all. The main facilities in Chenggu were the village leadership's office, an accessible health clinic, a small grocery shop (selling mainly dry goods), and a local agricultural supplies shop. In Beian, where the administrative villages have significantly larger populations, each administrative village had its own primary school, ${ }^{(10)}$ and some had a small hospital in addition to the village clinic. Small-scale commerce was also more common in villages in Beian, such as small eateries and shops selling basic daily required goods. For all other services and needs, the people in both counties needed to travel to the rural towns.

Finally, villages were also likely to lack master plans to guide development. In Beian, for example, new housing was laid out mainly in accordance with people's individual wishes, as long as they did not violate local construction regulations. In Chenggu, villages had plans in place long before the call to "build the new socialist countryside" was made. Yet, as several officials explained, these plans were very general, normally including only residential areas, and in reality were not strictly enforced. Occasionally, the size and shape of the housing plots was a legacy of the 1980s or earlier, and rural

5. Jiang Zhengmao, "Shehuizhuyi xin nongcun 'xin' zai nali?" (What is new in building the new socialist countryside?), Renmin wang (1 March 2006). Available at http://theory.people.com.cn/ GB/40537/4153232.html (accessed on 8 July 2013); Xu Li, "Xin nongcun jianshe 'xin' zai nali?" (What is new in Building the New Countryside?), Sichuan xinwen wang, available at http:// scnews.newssc.org/system/2006/04/10/000088942.shtml (accessed on 8 July 2013); for an official articulation of the BNSC program see http://news.xinhuanet.com/ziliao/2006-02/07/ content_4146460.htm (accessed on 8 July 2013).

6. These figures are officially cited by the Ministry of Water Resources. See www.mwr.gov.cn/eng lish/sdw.html (accessed on 8 July 2013).

7. According to Sun Zifeng, villagers were also likely to pay significantly more for electricity than their counterparts in the cities. See "Zhufang cunzhuang jianshe" (Housing and village construction), in Xiong Jingming (ed.), Jinru 21 shiji de Zhongguo nongcun (Rural China enters the twentyfirst century), Beijing, Guangming ribao chubanshe, 2000, p. 145

8. Wang Xianfeng, "Xin nongcun jianshe de beijing he tiaojian" (The background and conditions of the BNSC), in Li Zuojun (ed.), Zhongguo xin nongcun jianshe baogao (Report on building a New Chinese Countryside), Beijing, Shehui kexue wenxian chubanshe, 2006, pp. 30-31.

9. See, for example, Lili Lai, Discerning the Cultural: As Ethnography of China's Rural-Urban Divide, PhD dissertation, The University of North Carolina, 2008, Chapter 1.

10. In the past, every village in Chenggu County had its own primary school as well, but most of them were already merged into large modern schools located in the townships' seats or in large villages. 
inhabitants often built their houses in a haphazard pattern with narrow alleys running between them. In both counties it was common to see rural houses in various models, shapes, and sizes standing next to each other.

Yang's second point refers to a waste of land. China's rapid economic development and the erasure of previous restrictions on physical mobility have changed traditional residential patterns in the countryside. In a period of growing prosperity, many villagers have been building new houses for themselves or for their children, often occupying agricultural land. The new houses tend to require large plots of land, as it is common for the residential compounds to include private yards for daily usage. ${ }^{(11)}$ At the same time, many millions of village families have been flowing to China's cities to take up jobs, leaving behind houses that are empty for most or all of the year. This emigration, according to Yang, causes a serious waste of land.

Yang's third point refers to the dispersed deployment of villages in the countryside and the tendency of rural communities to be small in terms of population size. As a result, investment in infrastructure, public amenities, and services becomes excessively expensive, impeding the possibility of providing adequately for the needs of each locality.

The fourth point refers to rural economic patterns that render it difficult to adjust to the developing market economy. This includes factors such as fragmented land (due to the tiny plots of household farming), the prevalence of small-scale family economic ventures, decentralisation in decisionmaking, and old-fashioned business philosophy. As a whole, this hinders the possibility of creating economies of scale and introducing new technology, and ultimately impedes modernisation of the rural economy.

Yang's fifth and last point refers to the low capacity of local investment. This is a result of low incomes and the absence of financial surpluses; unwillingness to invest in undertakings that do not produce immediate and direct profit or personal benefit; weakening rural community collective consciousness; and increasing difficulty in forming a consensus to engage in common undertakings and construction. $\left.{ }^{12}\right)$

The solution to these impediments, according to Yang Shisong, is the creation of a new style of rural community.

\section{Constructing rural communities: Urbanising the rural}

In 2005 , during the fifth plenum of the $16^{\text {th }}$ NCCPC, a call was officially issued to "build a new socialist countryside" (BNSC) as a far-reaching solution to rural problems. Behind this call was the acknowledgment by Chinese policymakers that inequality and economic disparity, most notably between the rural and urban populaces, had reached a worrisome level and could no longer be ignored. In October 2006, at the sixth plenary session of the $16^{\text {th }}$ NCCPC, a call was conveyed to "actively promote the building of rural communities" as an indispensable part of the BNSC scheme.

The concept of communities is not new in China. The well-known Chinese sociologist Fei Xiaotong introduced the concept of shequ in the early 1930s as his translation of the word "community" in its sociological meaning of Gemeinschaft. ${ }^{(13)}$ The word, however, disappeared from public discourse when sociology was banned in the early 1950s and returned to official and scholarly discourse only in the 1980s, when sociology was rehabilitated as a discipline. (14) In the early 2000s, the Ministry of Civil Affairs reintroduced "communities" as a new form of administrative organisation in urban governance. According to David Bray, the creation of urban communities was mainly a result of the state's inability to "meet the demand for social serv- ices brought about by the rapid socio-economic transformation of urban China since the mid-1980s." (15) The solution was to create new neighbourhood-based administrative units in order to enable the state to regain its capacity to manage the urban populace.

According to the Ministry of Civil Affairs, a central aspect of the urban neighbourhood community is the provision of services to its inhabitants. According to the Ministry's instructions, these should include: (1) welfare services to those in need; (2) health services; (3) public cultural facilities, activities rooms, sports and cultural events, etc. (4) beautification of the community, enhancing cleanliness, greenification, and local awareness of environmental protection; (5) and community policing and educating the people to act according to the law, providing legal consultation, civil mediation, obeying the policy of family planning, etc. ${ }^{(16)}$ Typically, the structural characteristics of the urban communities include (1) a scale of 1,000-1,500 households living in apartment blocks; (2) clear boundaries, often through the creation of walled compounds; (3) and the establishment of activity centres. ${ }^{(17)}$

As in the case of urban communities, the government introduced the reshaping of rural communities as a remedy to poor rural organisation and service delivery. Unlike the cities, in which the bolstering of community life may be viewed as innovative vis-à-vis the nature of modern cities, in Chinese rural areas the notion of communal life is almost innate. ${ }^{(18)}$ From an official viewpoint, the superiority of the new rural communities over traditional rural villages lies in the larger population sizes, as authorities often expect several villages to form a community in a new residential location. This modern living environment among a concentrated population is supposed to enable villagers to enjoy living conditions and public amenities similar to the cities, in complete contrast to the "dirty, chaotic, and poor" characteristics of the dispersed villages.

As David Bray observes in his article in this journal issue, urban-style housing has become the model for the whole nation. Inside the communities, inhabitants are expected to enjoy modern housing and high accessibility to services. While the responsibility for importing urban-like models of architecture lies in the hands of the Ministry of Construction, responsibility for services lies in the hands of the Ministry of Civil Affairs. According to the Ministry, services entail social assistance to those in need, maintaining public order, health care, family planning, education, and sports. ${ }^{(19)}$ The list coincides perfectly with the Ministry's expectations of urban communities. To ensure a high degree of accessibility, the Ministry's instruction is that all services must be provided within a radius of

11. See Andrew Kipnis, Producing Guanxi: Sentiments, Self and Subculture in a North China Village, Durham, Duke University Press, 1997, p. 41. See also David Bray's article in this journal issue.

12. Yang Shisong, "Dui xin nongcun shequ jianshe de tansuo" (Exploring the construction of new rural communities), Juece tansuo, December 2011. Available at www.juecets.com/web/zazhi/ Show_List.asp?id=2441\&BigClassID=178 (accessed on 8 July 2013).

13. Zhu Qizhen, Lu Kerong, "Xin nongcun jianshe beijing xiade nongcun shequ fazhan" (Rural communities in the development of building the new countryside), in Zhu Qizhen, Lu Kerong (eds.), Xiangcun lüyou yu nongcun shequ fazhan (Developing rural tourism and rural communities), Beijing, Zhongguo nongye daxue banshechu, 2008, p. 2.

14. David Bray, "Building 'Community': New Strategies of Governance in Urban China," Economy and Society, Vol. 35, No. 4, 2006, pp. 530-531.

15. Ibid., p. 544.

16. http://blog.sina.com.cn/s/blog_6719a7390100hkwg.html (accessed on 8 July 2013).

17. David Bray, "Building 'Community': New Strategies of Governance in Urban China," art. cit., p. 539.

18. See, for example, Ferdinand Tönnies, Community and Society, New Jersey, Transaction Publishers, 1957. First published in Germany in 1887.

19. www.law-lib.com/law/law_view.asp?id=277030 (accessed on 8 July 2013). 
no more than 2-3 kilometres from homes and no more than 20 minutes' walking distance. (20)

\section{Urbanising the rural in Chenggu County, Shandong Province}

The transition from traditional villages to residential communities has been rapid in a substantial part of rural Shandong. In 2007, the Ministry of Civil Affairs selected 251 counties nationwide to serve as experimental sites for the creation of new rural communities, one of which was Chenggu. The two leading provinces on this list were Shandong (34 counties) and Jiangsu (33 counties). Together these two provinces served as a vanguard, leaving the rest of the provinces far behind. (21) By the end of 2011, the Ministry of Civil Affairs designated 106 counties as national "model units" (shifan danwei 示 范单位) in the project of constructing the new rural communities. The leading province by far was Shandong, with 27 model counties. ${ }^{(22)}$

Although Chenggu was not a model unit, its local officials took on communities as a high priority. In 2009, the county drew up a grandiose plan in which all of its 840-plus villages would be concentrated into 173 residential communities. Most of these communities were to host several villages living together. In that year, the deputy governor of Shandong Province conducted an inspection tour in Chenggu, during which he praised the county and especially one of its wealthiest townships where the project of constructing rural communities has developed fastest, and urged it to continue with this project as an example for the entire province. By mid-2011, construction had already started in 67 communities, of which 46 were in advanced stages of construction. (23)

Interestingly, all of the village, township, and county officials in Chenggu County to whom I spoke warmly welcomed the idea of creating rural residential communities. No doubt, provincial support for the policy and the selection of Chenggu as an experimental site put pressure on the county to push the construction of rural communities further. Yet it would be wrong to attribute their support to this factor only, as the officials I interviewed seemed to believe in the benefits of the project, and they gave several reasons. First, they said, the concentration of scattered villages into higher density residential areas would facilitate provision of public amenities and services to the villagers, a main BNSC goal. They also explained that such a project was affordable: the county was prosperous, and in most cases the construction of the new communities' public areas did not burden the villagers with compulsory payments, as building was paid out of income from the villages' collectively owned assets, local governmental subsidies, local publicly owned business groups, and voluntary contributions, in some cases from the villagers themselves.

No subsidies, however, were available for housing construction, and the villagers were expected to pay all of the cost of their new residences. But as land for new houses was provided free by the village, and villagers were only required to pay for construction costs, a new rural house/apartment cost only about $20 \%$ of the price of housing in the township and county seats. Local officials in most townships and villages thought villagers could afford this expense.

Local officials' second consideration was the need to save land. Officials from Chenggu's Construction Bureau estimated in 2011 that when all residential communities had been fully constructed and villagers had moved into apartment buildings, the county would be able to free $88,000 \mathrm{mu}$ of land for agricultural and industrial uses.

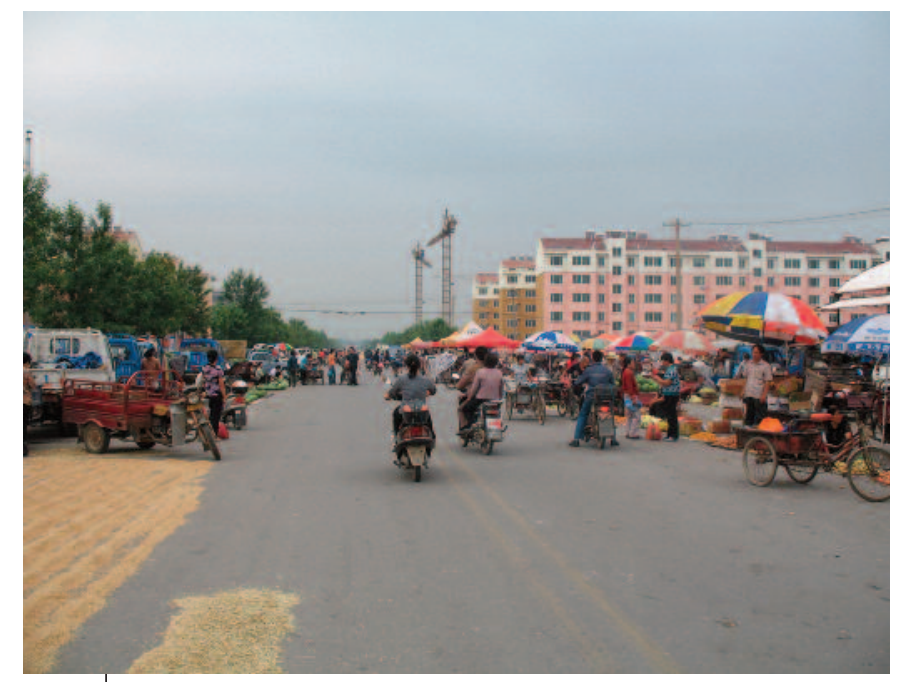

Photo 2 - An urban-like residential community in Chenggu County. ๑ Lior Rosenberg

It is not surprising that local officials were keen to free up land, as extra available land is important not only for increasing household earnings, an important BNSC goal, but also as a potential boost to local government revenues. The abolition of rural taxes and fees in the early $2000 \mathrm{~s}$ crippled local rural governments' capacity to generate revenue, so local officials turned to land as a source of finance. Illegal seizure and selling of villagers' land has become a widespread phenomenon in China. When I conducted fieldwork in Chenggu in 2011, the transition of rural inhabitants into residential communities had only recently begun. Officials insisted that even after transformation the land would still belong to the communities. All villagers I talked to confirmed that land remained under their village's control. Yet what is true today will not necessarily be true tomorrow. Whether local officials will attempt to use or sell the new acreage of vacant land is a matter for the future. After all, clearing land for new factory sites in the industrialised townships can generate new sources of revenue.

The importance of saving land is also manifest in the need to keep a minimum level of agricultural land (the so-called "red line"). According to the Law of Land Administration (1998), any occupation of agricultural land for non-agricultural usage must be accompanied by reclamation of the same amount of land of the same quality (article 31). Thus agricultural land reclamation in the county enables industrialisation on other plots of land.

In several villages I was told by local officials and inhabitants that local publicly owned business groups were investing in the construction of the compact high-rise communities. Officials insisted that these local business groups provided voluntary contributions. (24) Yet inhabitants of one of the county's most industrialised villages claimed that a contract had already been signed with a local business group promising it rights to the cleared land. According to them, the details of the contract were not transparent and village officials had never consulted them.

20. http://news.66wz.com/system/2010/10/17/102128111.shtml (accessed on 8 July 2013).

21. For the list of experimental sites see http://zqs.mca.gov.cn/article/cmzz/grb/200711/ 20071100004032.shtml (accessed on 8 July 2013).

22. www.chinabaike.com/law/zy/bw/gw/mzb/1343835.html (accessed on 8 July 2013).

23. Interview with officials from the Construction Bureau, Chenggu County, 18 May 2011.

24. On this, also see Chen Weixing, "The Political Economy of Rural Industrialization in China:Village Conglomerates in Shandong Province," Modern China, Vol. 24, No. 1, 1998, pp. 73-96. 
In short, land value is an important factor in the transition from villages to residential communities. At the time of my study, local officials deliberately chose first the wealthier villages, located near the county seat and in industrialising rural townships, to move and free their land.

Lastly, for many officials the transition from traditional rural houses to modern apartments symbolises the transition from backwardness to modernity. Many also equate lives in the villages to those in rural cities (the ultimate goal of BNSC) but also to those in developed Western countries. Clearly on this issue, though certainly not always on other topics, local officials' views coincide with the view of the central state.

For Chenggu officials, urbanisation in the county means the development of rural towns and urbanised rural communities and a better integration of these two systems. In light of this view, many of the new rural communities are being constructed adjacent to the country towns, serving as their de facto suburbs, sharing the towns' services, infrastructure, and labour markets. Also contributing to the integration is the very good road network in the county, which facilitates bus transportation from all of the villages/new rural communities to the towns and the county's economic zones. (25) Many of the roads inside the county had already been paved in the early 1990 s. However, as a result of the national policy of paving roads between administrative villages to establish a sub-county transportation network connecting villages, a second wave of road paving was launched by the county in 2003. According to the county's statistical yearbook, in 2007 all but ten villages located in the county's poorest township had roads accessible to cars. Although cars are still rare in most of the villages, small motorcycles are common and serve as a popular mode of transportation. All of the main roads to the township seats I visited are multi-lane and well paved, and buses run regularly all day long from the county seat to the townships. In 2004, all villages had already been connected to the bus network, offering the villagers bus services to both the township towns and the county seat. In 2010, the county government announced a new policy under which buses were to go through every village/community in the county (and not only to within one kilometre of a village, as was the case till then) and to offer subsidised transportation services, for which the county allocated 10 million yuan annually. The official deadline to complete this network was the end of 2011, a goal interviewees from the transportation bureau were confident of meeting. This excellent transportation network was expected to enable villagers to conveniently commute to work by bus every day while still living in their rural communities.

The transition from rural villages to urban-like communities embodies significant changes in villagers' lives. According to local plans, in most cases where several villages are merged a new community's population is expected to reach 2,000-4,000 inhabitants, whereas the average village in Chenggu currently only contains several hundred people. Often a new residential community, as in the cities, is surrounded by walls, accentuating its boundaries, its incorporation of villagers, and its integral identity vis-à-vis other communities. Inside the community multi-storey apartment buildings stand side by side.

All of the new apartments I visited in Chenggu were equipped with granite or tile floors and with modern facilities such as running water, solar water heaters, modern kitchens with methane gas for cooking, hygienic toilets, internet facilities, air conditioners, and in some of the villages even central heating systems. These amenities contrast sharply with the old, dirty, crude, and very basic facilities in the rural houses villagers had left behind.

All of the paths leading to and between the houses inside the community's

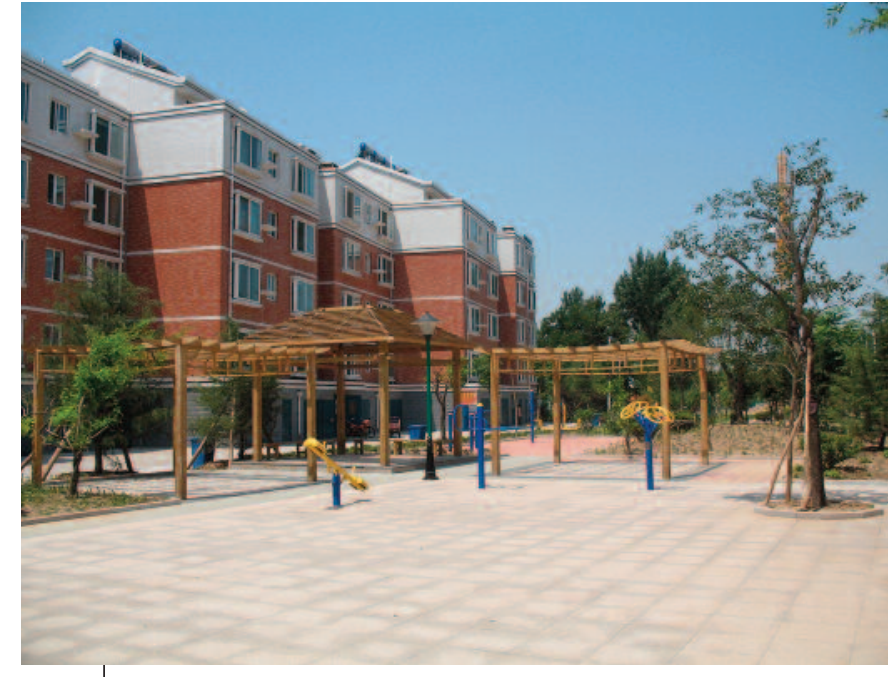

Photo 3 - An urban-like residential community in Chenggu County. @ Lior Rosenberg

jurisdiction were paved, a sharp contrast to the muddy-after-rain appearance of old-fashioned villages. As in the cities, local officials made the new living environments cleaner and greener. Trees, shrubs, and flowers were planted along the main roads and public areas, and garbage disposal facilities were introduced or improved. Streetlights were installed along the main roads, and in some cases surveillance cameras have been installed in the residential communities "to ensure the villagers' safety."

Public squares and sport facilities such as croquet courts, basketball courts, and outdoor sports facilities have been introduced in each rural community. Reading rooms have been constructed, offering reading material in residents' leisure time. Small-scale supermarkets have also been built, significantly larger than the previous grocery stores that operated in the villages, easing the previous inconvenience of buying daily products outside the village in the township seat or at rural markets. Often retirement homes have been built as well, to which villagers can move after the age of 60 .

Service centres have been constructed where residents can submit applications relating to issues such as birth control and land and residential approvals, which previously were accessed only in the township seat. This not only benefits the villagers but also reduces pressure on the township administration. Other services include local policing, civil mediation, welfare support, social security, economic assistance to those in need, pre-schools, schools, and health clinics offering doctors and drugstore services.

Notwithstanding these many advantages, moving to apartments may also embody adverse changes in villagers' living habits and customs. Apartments are often smaller than traditional rural housing. Social networks may be interrupted since people in most cases find themselves with new neighbours. Villagers no longer have an internal courtyard, which had many uses, such as corralling livestock, planting vegetables for self-consumption, or as storage place. When people move to a new area, they may find it less convenient than before, for example if they live far from their agricultural land. Finally, in most of the villages I visited in Chenggu, people are expected to move before getting compensation for their old houses or confiscated agricultural land. In light of all these factors, one may wonder, why do they agree to move?

25. The distance from the county seat to its most remote border at the northeast part is about a one-hour drive by car. 
The following is based on the many conversations I had with villagers in Chenggu. First and foremost, villagers move because they perceive the shift from the "old" and backward villages to living in a modern and hygienic environment as a "fair deal," even if that means living in smaller housing units. In addition, in developed Chenggu, villagers acknowledge the importance of saving land as a means for further industrialisation and wealth accumulation. A third factor refers to perceptions. During my conversations it became clear that for many villagers the transition from rural houses to apartments symbolises a transition from backwardness to modernity, and living in apartments is "living like in the cities," a notion embraced by many of the villagers. Lastly, all the communities that I visited were built fairly close to the original "old" villages. The new location therefore was not perceived by the villagers as an issue. They were still living close to their land, and even though previous neighbours may not share the same building, villagers still live together in the same residential compound and maintain social networks as easily as before. In new communities where several villages were expected to reside together, the new residential buildings are allocated per village to ensure that villagers from the same village continue to reside together. In many of the new multi-storey buildings, warehousing space and enclosed parking lots are allocated along with the apartments (or can be bought separately), providing even better storage than before. Thus local officials' positive perception of establishing residential communities coincided with the viewpoint not only of their superiors but also of many of the villagers.

Yet some villagers harbour suspicions about the new lifestyle. Regardless of individual economic conditions that may impede the possibility of buying a new apartment, there were other causes for hesitation. Villagers may consider it more convenient to stay in their old ramshackle ground-level house than to live in a modern clean apartment on the fifth floor without an elevator (if they could not afford to buy a more expensive unit on a lower floor). In addition, some simply prefer living amidst rural nature rather than in dense urban-like residential compounds. Especially in villages in which inhabitants are more dependent on agriculture and other rural undertakings for income, people were disturbed by the thought of living without the multipurpose internal yard or raising livestock in a separate area far from their watchful eye.

Notwithstanding these concerns, my overall impression was that cases of reluctance were a minority and mostly occur before and during the early stages of the transition. As long as they can afford it, ultimately most villagers seem to support leaving their old village. Normally when a new community is being built, the construction is conducted in several stages and not all apartment buildings are constructed at the same time. There are several reasons for this, among them financial constraints. Moving whole villages requires significant financial investment, while gradual construction can ensure a circulation of liquid finances. Lack of available land is another important reason. Often there is not enough land available for the entire construction project. In these cases, some of the apartment buildings are constructed first, and then after villagers have moved and their old houses were demolished, new apartment buildings are constructed on the evacuated land. Another important reason is to ensure that apartments do not stay empty when construction is over. In some cases villagers who wish to move may be asked to commit first, and only after a considerable number of households have committed will construction start. In other villages, officials were confident that by the time the first stage of construction was finished there would be enough households wishing to inhabit the new buildings. Moreover, officials believed that the best strategy to reduce cases of reluctance is to show sceptics a completed building so that they can witness the many benefits embedded in living in modern residences. In all of the villages I visited that were in a period of transition, the first to move were normally the villages' officials and young people, while others moved after learning from the experience of those who had already moved.

Officials tended to disparage the reluctant movers. For them, the new residences represent a new dawn for the countryside. The entrance to the new communities symbolises the entrance to modernity and to a better world. Why would a rational person resist such an opportunity? Especially in the richer areas of the county, officials also tend to disparage the notion that families face economic constraints, and in many villages and townships I was told that these simply do not exist (many villagers, though, have claimed the opposite). When asked about the possibility that villagers may find themselves residing next to unwanted neighbours, an official in one of Chenggu's most developed communities was decisive in his answer: "Hasn't this occurred in the cities as well? If you don't like your neighbour you can always buy an apartment in another building." (26) Officials made very clear that for them any reluctance to move was first and foremost a manifestation of backwardness of the villagers. Urbanising the rural is not only about constructing urban-like residential compounds and improving services; it is also about urbanising the people's minds and the creation of "new villagers" of "higher quality" (suzhi 素质).

\section{Urbanising the rural in Beian county, Anhui Province}

After the announcement of the BNSC scheme in 2006, officials in Beian started to introduce better infrastructure and public amenities in villages. These included paving all roads inside and between the villages, which in Beian were all dirt roads before 2006; installing running water; greening and beautifying the villages; introducing and/or improving garbage disposal facilities; and introducing cultural facilities such as public squares, basketball courts, outdoor sports facilities, and reading rooms. Yet unlike in Chenggu, officials in Beian were reluctant to construct new residential communities and multi-storey apartment building compounds. Why have officials in Beian not welcomed this as officials in Chenggu did? Why would they resist constructing "a gateway to modernity"?

The first important reason was that Beian was not included in the national list of experimental counties to construct rural communities. Without pressure from above, it was left to county officials to decide, and they have mainly used local economic factors to decide their development. Officials in Beian assumed, probably rightly, that requiring people to move to new homes or apartments will invoke serious resentment, possibly even social unrest, an outcome they try to avoid as much as possible. They suspect two main groups of residents would resist buying new housing and leaving their old villages. The first group consists of those who recently constructed a new house. As a less industrialised and less economically developed county, wealth accumulation in Beian is a slower process than in Chenggu, and many of the county's villagers have built new houses only recently. In most cases these houses are quite large (most of them are two-storey houses) and still in good condition. These villagers therefore do not feel the need to move. Moreover, unlike officials in Chenggu, officials in Beian perceive buy-

26. Interview with township officials, Chenggu County, 16 June 2009. 
ing new housing, which costs about the same as in Chenggu although incomes in Beian are lower, as a gigantic expense for households. Thus, they estimate that the villagers are unlikely to agree to move without getting adequate compensation, which the county in its current financial condition cannot afford paying.

The second group officials consider potentially problematic are the younger villagers. As the county cannot provide employment opportunities to all of its inhabitants, about a third of its entire population are migrant workers who are absent from the village for most of the year. Officials estimate that they are likely to refuse to buy new houses that they cannot use. Also, unlike in Chenggu where saved land can be translated into further wealth accumulation both for rural inhabitants and the local government, in most Beian villages the realistic scenario is agricultural land extension. Taking into account the unprofitability of agriculture for villagers and even more so to local governments' revenue, the county government decided that developing the local labour market and attracting investors were much more urgently needed than reclaiming agriculture land and urbanising outmigrating communities.

Finally, as Beian villages do not enjoy any significant collective income and therefore do not have collective revenues to support redevelopment of public village facilities, the success of any redevelopment is heavily dependent upon the willingness of the villagers to pay for new infrastructure themselves. Constructing new residential communities would entail creating even more expensive new infrastructure and amenities. Officials in Beian were very sensitive to not over-burden the villagers with new expenses.

Instead, efforts were being made by the county government to develop its rural towns, and especially to develop the township of G.H., where the county government is located, into the main urban, commercial, and industrial centre. The hope is that this will bring many of the county's migrant workers back home and that people will (voluntarily) leave their overpopulated backward villages and move into the township's new residential areas, some of which are still under construction. The plan, according to official documents, is that $80 \%$ of the county's population will eventually reside in the county's rural towns, with access to the towns' facilities, infrastructure, and public amenities. Signs of change are already noticeable. According to local statistics, in 2007 , only $10 \%$ of the county's population held a non-rural household registration. Yet in the township of G.H., over $40 \%$ of the township's population already hold a non-rural household registration. Under the circumstances of underdevelopment, the official view in Beian was clear - first comes "urbanisation from below," and only then can the rural be urbanised.

Officials fully acknowledged that industrialisation and developing local labour markets may take a long time, as Anhui is not a highly industrialised province. Rather than constructing new residential communities, they have happily embraced the idea of less ambitiously focusing on enhancing "community services" with a goal of offering better urban-like public amenities and services in the villages.

\section{Discussion and conclusions}

When the official call to construct new rural communities was aired in 2006, Chenggu was already an economically developed county. Its labour market offered employment opportunities not only to its own inhabitants but also to many thousands of migrant workers, who were flowing into the county from all over the country. About a quarter of its population held non-rural hukou and about half of the county's total population lived in the county's rural towns, (27) enjoying excellent infrastructure, public amenities, and markets. Public transport and an excellent road network had already been established interconnecting all rural towns and villages. Under these circumstances, villagers and officials welcomed constructing urban-like residential areas with modern facilities, accessible high-quality services, and better economic structure as a natural continuation of the county's two decades of economic development.

While officials in Chenggu were excited about the construction of new rural communities, in less developed Beian County officials rejected the idea. To be sure, as in Chenggu, officials in Beian identified the impediments of the "old" countryside as a problem and strongly believed that a "new" countryside is needed. They did not reject the idea of constructing rural residential communities as embodying potential benefits, but they questioned whether it was appropriate for their current local conditions. Since Beian lags behind Chenggu in terms of economic development, its present worries coincide with Chenggu's past ones. The official view in Beian is to promote prosperity in the county through further development of town local labour markets. As in Chenggu, officials in Beian value urbanisation to boost the local economy and modernisation - but in their view, under the county's current circumstances, this should be a product of market forces much more than through direct state intervention. For them, it is not time to urbanise the villages yet.

Provincial levels recognised the need for a prosperous rural base to successfully create new rural communities. In 2005, for example, on the eve of BNSC and before the Party officially aired the national call to construct rural communities, the province of Shandong published a document in which it articulated its main policies for the impending BNSC scheme. All counties were divided into three groups by their level of CDP. Counties that were included in the first group of highest GDP in the province (one of which was Chenggu) were expected to concentrate industries in industrial zones, to concentrate population in the counties' and central townships' seats, and to concentrate villagers into rural residential communities. Rural and urban systems were to be better integrated in terms of economy, infrastructure, employment, social welfare systems, and environment protection. Often this is met by locating residential communities adjacent to rural towns as de facto suburbs.

The province's expectations for the third group of counties with the lowest GDP were significantly less demanding and more appropriate to their poor economic conditions. These included improving the physical living environment in the villages, improving villagers' professional skills, improving basic infrastructure and amenities inside the villages, and improving village officials' leadership. Unlike the developed counties, where the provincial focus was on integration between rural and urban communities, here the focus is on improving local conditions inside the villages, with the hope that with time they will be able to improve their conditions and meet the province's requirements for its developed counties. (28)

The cases of Chenggu and Beian, which fully coincide with Shandong's schema, make it clear that while imposing urban models of residence may

27. Chenggu County Statistical Yearbook, 2008.

28. Fu Ruren et al.,"Guanyu dui Shandong sheng shehuizhuyi xin nongcun jianshe jiaqiang fenlei zhidao de zonghe yanjiu baogao" (Integrated research about strengthening guidance in building a new socialist countryside in Shandong Province), in Fu Ruren (ed.), Xin nongcun jianshe jiaqiang fenlei zhidao: yanjiu yu tansuo (Strengthening guidance in building the new countryside: Research and exploration), Jinan, Huanhe chubanshe, 2007, pp. 12-7. 
be appropriate for developed rural areas, this does not fit local conditions elsewhere.

Migrant workers, for example, may refuse to buy new housing that they cannot use. In areas where agriculture is still a major source of household income, and in hilly or other areas where villages are extensively dispersed, concentrating the population in new residential compounds may invoke serious difficulties for those displaced. Even in developed Chenggu, where according to local statistics $70 \%$ of the villagers' income is derived from non-agricultural resources, ${ }^{(29)}$ and where non-rural employment is highly available and accessible, villagers sometimes worried about storing agricultural tools or living removed from their land and livestock.

Moreover, construction of residential communities requires significant financial investment. According to a local document, by the end of 2009, total investment in the construction of rural communities in Chenggu already totalled a billion yuan. Clearly, it would have been impossible in most rural counties to meet the high standards of Chenggu, especially bearing in mind that most localities in China are heavily in debt.

What also serves as a serious concern is the embedded lack of transparency in the Chinese political system and the inability of higher levels to control implementers and to suppress corruption and embezzlement by local officials. ${ }^{(30)}$ This is worrisome, as the creation of new rural communities necessarily involves large-scale construction projects and land transfers, two main sources of local corruption in contemporary China. There already is evidence of local officials taking advantage of the call to construct new rural communities. This includes, among other things, illegal sale of villagers' land, deprivation of villagers' basic legal rights, inadequate compensation for loss of land or housing, forcing villagers into debt to buy new housing against their will, expelling villagers from their homes and in some cases placing them in provisional housing lacking basic facilities, and illegal shifts of property from villagers to companies in which local cadres or their kin have financial interests. ${ }^{31)}$

Lastly, as a statist venture, constructing rural communities may easily tilt towards meeting state goals much more than villagers' well-being. Most villagers whom I conversed with in Chenggu made it very clear that no one has asked them whether they would like to leave their villages or to move to communities and to multi-storey apartment buildings. Indeed, it seems that villagers' ability to influence local officials' decision-making was slim. County construction bureau officials told me that geographical location was their main consideration in deciding which villages were to be concentrated into new communities and reside together. Whether the villagers agreed or not was clearly not their concern. In several communities, villagers said that their opinion was never asked regarding housing models or what was to be included in the community's jurisdiction. In many aspects, grassroots officials' discretion was also limited. It is not surprising that in both Chenggu and Beian, itemising what was to be included in the shaping of villages/communities reveals many similarities, such as greenification, introducing sports facilities, e.g., basketball courts and outdoor facilities, etc. These were all articulated by the central government and by higher levels of the local state as a compulsory formula to establish a new countryside. In both counties, grassroots officials were provided with detailed lists from higher levels of the government itemising what is to be constructed, with little discretion left for the implementers. Excluding villagers from participating in decisionmaking and counting on urban wisdom to solve rural problems risks serious misunderstanding of local rural circumstances. The more rural, the greater the potential misapprehension.
Yet it seems that central policymakers are determined to expand the construction of rural communities and at a rapid pace. In October 2010, a national conference was held in Ningxia entitled "Obvious effects of the national experimental work in (the construction of) rural communities." The ranks of the participants left no doubt about its importance. These included the Deputy Minister of Civil Affairs and leaders from every province and city. Senior officials praised experiments in constructing new rural communities at the conference. The Deputy Minister stressed the serious shortage of services in rural China, conveying a call to create rural communities in $30 \%$ of China's counties by the end of 2011. The conference called for a gradual expansion of the construction of rural communities to "remote areas with poor natural conditions and transport," located in "areas with poor economic conditions, forestry areas, pastoral areas, fishing areas, and other rural areas." (32) Although the word "gradually" was used, the schedule announced at the conference left no time for idling. By 2015, all rural areas in the country were expected to carry out the construction of new rural communities, with more than $60 \%$ of the communities basically constructed. By 2020 , all rural communities nationwide are to be built, offering communal social life with orderly management and complete services. ${ }^{(33)}$

A year later, a Ministry of Civil Affairs document referred to the rural communities as "guaranteeing that hundreds of millions of farmers enjoy the fruits of reform and development." (34) This expectation of a rapid nationwide construction of rural service communities is of great concern. As noted earlier, one of the main reasons for officials constructing urban-like dense residential communities was to improve the provision of services, which could not have been provided efficiently when the rural populace was scattered in the countryside. The earlier-mentioned demands of the Ministry of Civil Affairs that all services must be provided within a radius of no more than 2-3 kilometres and no more than 20 minutes' walking distance serves as another driver of concentration regardless of local circumstances.

No doubt such clear messages by high-ranking figures do not fall on deaf ears. By 2011, most of the townships in Chenggu that I researched had already changed local regulations. Construction of any other style of housing apart from multi-storey buildings was officially banned. These included townships in which officials had explained to me only two years earlier that they would never impose any model of residence on the villagers, as this contradicts their own beliefs about what the new socialist countryside entails. Two years later the die had been cast - the rural scene is to be changed forever.

The construction of rural communities has become an ambitious nationwide policy that seeks to change China's countryside dramatically through statist social engineering, relocating populations, and imposition of urban

29. Chenggu County internal document.

30. For example, Ben Hillman, "Factions and Spoils: Examining Political Behavior within the Local State in China," The China Journal, No. 64, 2010, pp. 1-18.

31. Blogs have become a popular means for individuals to lament the hardships and injustice they encounter in their everyday life. The following are a few examples that relate to the BNSC program. For Henan see http://bbs.city.tianya.cn/tianyacity/content/492/1/3733.shtml; For Yunnan see http://wqw2010.blogspot.com/2011/12/blog-post_9713.html; For Zhejiang see http://blog.19lou.com/14684857/viewspace-3455178; For a blog lamenting cadres' corruption and lack of concern for the villagers and their needs see http://bbs.blog.99.com/t-528-1.htm. All links were accessed on 8 July 2013.

32. http://news.66wz.com/system/2010/10/17/102128111.shtml (accessed on 8 July 2013).

33. Ibid.

34. www.mca.gov.cn/article/zwgk/fvfg/jczqhsqjs/201103/20110300137209.shtml (accessed on 8 July 2013). 
settings on rural communities. The idea of imposing urban models on rural communities as an administrative means to solve rural problems is provocative. Merging villages is even more so. According to officials in Chenggu, after all of the villagers have been moved, the next step would be merging them politically and financially under a unified community leadership. As each village has its own economic resources and as some have been more successful than others, such a move would likely encounter bitter resistance. Some officials in Chenggu in a burst of candour admitted that thus far no one in the county had succeeded in resolving this impending problem.

As the cases of Chenggu and Beian clearly demonstrate, constructing rural residential communities fits prosperous communities' circumstances. But as the policy gains popularity in the eyes of central officials, it raises real concerns for the future of most of China's rural population. If handled wisely, it may benefit both villagers and the state. If not, it may easily become a statist venture of predation and a source of tension and rural discontent. How the program will affect China is still to be seen, and still for the state to decide.

I Lior Rosenberg has completed a PhD dissertation at The Australian National University. This year he has taught on Chinese society at Tel Aviv University.

The Australian National University, Acton ACT 0200, Australia (lior.rosenberg@anu.edu.au). 